\title{
Managerial Incentives and Audit Fees: Evidence from the Mutual Fund Industry
}

\author{
James Ross Booth \\ Department of Finance, DePaul University \\ 1 E. Jackson Blvd., Chicago, IL 60604, USA \\ Tel: 1-312-362-6566 E-mail: jbooth3@depaul.edu \\ Lena Chua Booth \\ Thunderbird School of Global Management \\ 1 Global Place, Glendale, AZ 85306, USA \\ Tel: 1-602-978-7418Ｅ-mail: lena.booth@thunderbird.edu \\ Daniel Deli (Corresponding author) \\ Department of Finance, DePaul University \\ 1 E. Jackson Blvd., Chicago, IL 60604, USA \\ Tel: 1-312-362-6888Ｅ-mail: ddeli@depaul.edu
}

Received: April 2, 2012

Accepted: April 25, 2012

Published: May 15, 2012

doi:10.5430/afr.v1n1p76

URL: http://dx.doi.org/10.5430/afr.v1n1p76

\begin{abstract}
We examine the relation between audit fees and managerial incentives in the mutual fund industry. We find that audit fees are higher when managerial incentives with respect to reporting are poor. Our results suggest that the auditing profession, at least to some extent, recognizes the adverse incentives created by certain organizational and contracting arrangements and prices auditing services to reflect those adverse incentives.
\end{abstract}

Keywords: Audit Fees, Mutual Funds, Certification, Incentives

\section{Introduction}

Researchers have long considered the demand for audit quality as a function of managerial agency costs. For example, Palmrose (1984), Francis and Wilson (1988) and Defond (1992) examine the link between managerial incentives and auditor choice for existing public firms. Datar, Feltham, and Hughes (1991), Feltham, Hughes, and Simunic (1991), and Clarkson and Simunic (1994) also examine managerial incentives and auditor choice, but in the context of initial public offerings. Researchers have also considered the supply price of audit services. For example, Simunic, and Stein (1994) and Bell, Landsman, and Shackelford (2001) examine the relation between audit fees and auditor business risk (Note 1). Likewise, Hogan and Wilkins (2008) find that audit fees are higher for firms with internal control deficiencies. Also, Chen, Chung, and Wynn (2009) find that audit fees are higher when internal audit managers receive incentive based compensation. Our study is similar in nature to the demand side studies in that we are interested in the role of managerial agency costs in determining audit outcomes. Like the supply side studies, however, we focus on audit fees rather than auditor identity (or size). Specifically, we focus on the link between audit fees and managerial incentives.

We identify two potential sources of managerial agency costs. The first source is a conflict between fund managers and fund investors. Investors are assumed to be less than fully informed with regard to managerial actions and the demand for audited financial numbers used in contracting follows. Recent research suggests another potential managerial agency problem as well, however. That research (discussed below) suggests that the managerial propensity to misrepresent performance measures (what we refer to as "poor managerial incentives" hereafter) increases with the sensitivity of managerial wealth to firm value. If that propensity is recognized by audit firms, then presumably it will be reflected in 
audit fees. We expect, then, that when managerial agency costs are large audit fees will also be large.

We examine the link between audit fees and managerial incentives in the mutual fund industry for several reasons. First, Fama and Jensen $(1983 a, b)$ note that fund organizational form proxies for managerial incentives. They argue this arises because open-end funds offer "a special form of diffuse control" in that investors, by redeeming their shares, may affect what amounts to a partial takeover or liquidation of the fund. The constant threat of withdrawal of fund assets serves as a disciplining force for open-end advisors. This same disciplining force is not present for closed-end funds whose shares trade in the secondary market. The absence of a disciplining force leads to poorer incentives for closed-end fund advisors than for open-end fund advisors (Note 2). We argue that the difference in managerial incentives associated with the different organizational forms allows for a powerful test of the relation between audit fees and managerial incentives. Second, the large number of mutual funds (and hence, the large number of sample observations) enhances the power of our empirical analysis. Third, mutual fund advisory contracts are publicly available and simply specified. This allows us to create a very precise measure of advisor marginal compensation (which we use as another proxy for the incentive to misrepresent performance). Finally, fund type and holdings are readily identifiable which allows us to precisely control for other factors that may affect audit fees.

Our expectation is that audit fees are positively related to poor managerial incentives. Using three different proxies for managerial incentives with respect to reporting, our results are consistent with that expectation. For example, we find that closed-end funds have significantly higher audit fees than their open-end fund counterparts. The mean audit fee for an open-end equity fund is $\$ 33053$. The mean audit fee for a closed-end equity fund is $\$ 71018$. The difference is not explained by other factors related to the level of audit fees (such as fund size, type, or auditor identity).

We also examine the relation between audit fees and managerial incentives as captured by advisor marginal compensation rates. We find that for both open-end and closed-end funds, audit fees are positively related to marginal compensation. When fund advisor wealth has its greatest sensitivity to fund value audit fees are higher. We also find that the relation between marginal compensation and audit fees is even greater for closed-end funds. These findings, together, are consistent with the notion that the audit market prices managerial incentives - charging higher prices when those incentives are poorest.

Fund expenses provide another avenue for examining the link between managerial incentives and audit fees. Mutual fund research suggests that excess fund expenses proxy for an environment consistent with poor managerial incentives [Tufano and Sevick (1997) and Del Guercio, Dann, and Partch (2003), and Zitzewitz (2003)]. Relying on the findings of those studies, we examine the relation between audit fees and excess expenses. We find that audit fees are greater when excess expenses are greater. That result is consistent with the expectation that audit fees increase with poor managerial incentives.

Finally, we find that mutual fund audit fees are also determined by factors previously found to drive audit fees in industrial firms. For example, we find that audit fees are increasing in audit scope and that they exhibit economies of scale. Additionally, we find evidence that audit fees are increasing in audit complexity. For example, we find that audit fees are higher for funds that invest in assets that are difficult to value or funds that implement trading strategies that rely on investing in complex assets. Specifically, we find that funds that invest in restricted securities and funds that invest in derivatives have significantly higher audit fees than funds that do not invest in restricted securities or derivatives.

Our research is the first to make the link between managerial incentives and audits fees. Our results suggests that the auditing profession, at least to some extent, recognizes the adverse incentives created by organizational arrangements and compensation schemes tied to firm value and prices auditing services to reflect those incentives.

The rest of the paper proceeds as follows. In section 2 we provide background on the auditing of mutual funds as well as develop our hypothesis with respect to the link between managerial incentives and the demand for audit certification. Section 3 describes the sample and provides preliminary analysis. Section 4 reports results from multivariate analysis of the relation between managerial incentives and the demand for audit certification. Section 5 presents robustness tests and provides further discussion of our results and section 6 concludes.

\section{Background and Hypothesis Development}

In this section we first explore the procedures involved in auditing mutual funds. We then develop the formal hypotheses linking audit fees to managerial incentives. Finally, we discuss factors previously shown to affect the level of audit fees.

\subsection{Audit procedures for mutual funds}

The American Institute of Certified Public Accountants (2002) defines several principal objectives with respect to the audit of mutual fund portfolio assets including determining whether portfolio investments are properly valued (Note 3 ). 
For example, the AICPA suggests "The auditor should test all portfolio valuations as of the date of the financial statements." Further, the auditor should consider "testing transactions on dates selected from the period under examination for agreement with the values computed by the [fund]." To do so, the AICPA suggests that auditors consider obtaining independent quotes or reviewing the procedures used by pricing services for determining quotes (Note 4). Thus, a central issue in the audit process is determining the appropriateness of portfolio asset values.

Additionally, auditors are charged with the responsibility for considering whether fund internal controls provide appropriate assurance that material pricing errors would be prevented or detected. For example, the AICPA suggests that such control procedures might include: (1) checking methods used by the pricing service (if one is used) to obtain daily prices, (2) verifying large price changes that occur over a short period of time, (3) confirming dealer quotations with other dealers, and (4) maintaining a comparison of actual sales prices with the value used for the previous day [AICPA (2002)]. Again, the AICPA's suggestions highlight the centrality of asset pricing to the audit process.

\subsection{Hypothesis Development}

Casual observation of the assets under management in open-end funds and closed-end funds suggests that open-end funds must typically offer advantages that lead to the overwhelming majority of fund investments being made in open-end funds. Following the arguments of Fama and Jensen (1983a,b), we suggest that an important advantage of open-end funds is a reduction in agency costs stemming from investors' ability to redeem shares at NAV.

Investors in open-end funds have the right to redeem their shares at NAV. That is, they can realize their proportional claim on the market value of the underlying portfolio assets. This is not the case for closed-end funds. Closed-end fund shares trade in the secondary market at prices potentially different from NAV. Closed-end fund shares tend to trade at discounts to NAV [e.g., Zweig (1973), Malkiel (1977), Brauer (1984), and Lee, Shleifer, and Thaler (1991)]. Barclay, Holderness, and Pontiff (1993) provide evidence that at least a portion of the discount is explained by opportunistic behavior by closed-end fund advisors. Following the lead of that research, we assume poorer managerial incentives in the case of closed-end funds than in open-end funds.

The assumption that managerial incentives are poorer in closed-end funds than they are in open-end funds begs the question of the existence of closed-end funds. We note, however, that while open-end funds economize on agency costs between fund managers and investors, closed-end funds offer other economies. For example, closed-end funds mitigate conflicts among investors with different horizons and between existing investors and potential investors [Deli and Varma (2002)]. Chordia (1996) argues that the closed-end organizational form mitigates costly opportunity costs associated with cash balances held by open-end funds to meet redemptions. Edelen (1999) suggests that the closed-end organizational form can also mitigate costs associated with trading forced by net flows in and out of a fund. Thus, while closed-end funds involve poorer managerial incentives, they also offer advantages that allow for their continued existence in equilibrium.

Jensen and Meckling (1976) and Watts and Zimmerman (1986) argue that in situations involving conflicts of interest between contracting parties, the parties have the incentive to develop mechanisms to reduce the costs of those conflicts. As Watts and Zimmerman (1986) note, however, those mechanisms would be of little use if their provisions were not monitored and enforced. Auditing plays a central role in certifying the inputs to those mechanisms used to overcome costly agency conflicts.

There is a large literature documenting the pervasiveness of contracts under which advisor compensation is tied to net asset value [Starks (1987), Grinblatt and Titman (1989), Stoughton (1993), Heinkel and Stoughton (1994), Admati and Pfleiderer (1997), Coles, Suay, and Woodbury (2000), Deli (2002)]. The pervasiveness of contracts tied to net asset values suggests that the inputs required for net asset value calculations are of central importance to the contracting process. There are at least two reasons to believe that closed-end funds will seek greater certification of those inputs than open-end funds. As previously discussed, unlike open-end funds, closed-end funds do not have the disciplining mechanism offered by redemption. Also, because closed-end funds are not subject to the possibility of redemptions, manipulations of contracting numbers, such as fund value, seem more likely to persist (Note 5).

The above arguments suggest closed-end funds offer poorer managerial incentives and the opportunity for the manipulation of numbers used in the contracting process. That agency conflict leads to a greater demand for audit certification. Other studies assume that incremental audit fees (i.e., controlling for factors known to affect fees such as auditor reputation) proxy for demand for audit certification [Abbot, Parker, Peters, and Raghunandan (2003), Coulton, Craswell and Taylor (2001), and Carcello, Hermanson, Neal, and Riley (2002)]. Because managerial incentives are poorer in closed-end funds and because funds will demand greater certification when managerial incentives are poorer, we expect that closed-end funds will have greater audit fees than their open-end fund counterparts. 
It is also the case that supply side factors may affect the level of audit fees as well. For example, differences in managerial incentives may affect the level of audit risk which, in turn, affects the level of audit fees either because auditors price the risk directly or because they adjust the level of audit effort to mitigate the risk. Davis, Ricchiute, and Trompeter (1993) document that incremental audit effort is costly and reflected in audit fees. Hogan and Wilkins (2008) find that audit fees are higher for firms with internal control deficiencies. Thus, supply side factors related to managerial incentives could lead to higher audit fees for closed-end funds as well. Both demand and supply side factors suggest that closed-end funds will have higher audit fees. Consequently, without trying to distinguish between the two, our first hypothesis is that closed-end funds will have higher audit fees than their open-end fund counterparts.

Advisor compensation may offer another mechanism for examining the effect of managerial incentives on audit fees. Gao and Shrieve (2002), Cheng and Warfield (2005), Bergstresser and Philippon (2006), Peng and Roell (2005), Efendi, Srivastava, and Swanson (2007), Cohen, Dey, and Lys (2008), and Cornett, Marcus, and Tehranian (2008) find an association between equity-based compensation and earnings manipulation. Johnson, Ryan, and Tian (2009) and Erickson, Hanlon, and Maydew (2006) document a positive association between equity-based compensation and a firm being accused of fraud by the SEC. Similarly, Richardson, Tuna, and Wu (2003), Burns and Kedia (2006), and Kuang (2008) find that the likelihood of earnings restatement is positively related to equity-based compensation. Also, Chen, Chung, and Wynn (2009) find that audit fees are higher when internal audit managers receive incentive based compensation. In sum, these recent studies find that managers are more likely to manipulate or misrepresent accounting measures as the sensitivity of their wealth to firm value increases. If those results generalize to the mutual fund industry, and if the incentive were priced in audit fees, then we would expect that higher audit fees being observed in instances where advisor compensation is more sensitive to fund value. Our second hypothesis, then, is that when fund manager compensation has a greater sensitivity to the value of the fund, audit fees will be higher.

In addition to advisor compensation, fund expenses provide a useful mechanism for examining the relation between audit fees and managerial incentives. Tufano and Sevick (1997) and Del Guercio, Dann, and Partch (2003), and Zitzewitz (2003) argue that fund expenses in excess of those explained by the nature of a fund's assets are a function of poor fund governance and resulting managerial opportunism. For example, Tufano and Sevick (1997) and Del Guercio, Dann, and Partch (2003) find board characteristics generally associated with poorer fund governance are associated with higher expenses. Zitzewitz (2003) finds that funds with greater excess expenses are less likely to adopt measures that prevent short-term trading strategies harmful to long-term fund investors. We follow the spirit of their work and examine the relation between audit fees and excess expenses (net of audit fees). Our third hypothesis, then, is that audit fees will be higher for those funds with greater excess expenses.

\subsection{The general determinants of audit fees}

Simunic (1980) suggests three broad factors that determine the level of audit fees that are relevant for our study: (1) the size of the auditee, (2) the complexity of the auditee's operations, and (3) audit difficulties associated with certain types of assets (Note 6). Consistent with Simunic's first suggestion, there is a large empirical literature documenting a positive relation between audit fees and auditee size [c.f., Simunic (1980), Chow (1982), Firth (1985), Craswell, Francis, and Taylor (1995), Francis and Simon (1987), Palmrose (1986), Simon and Francis (1988), Low, Tan, and Koh (1990), and Turpen (1990)]. This suggests that it is important that we control for auditee size when examining the relation between audit fees and managerial incentives. Similarly, it is the case that there may be economies of scope when auditing funds within a mutual fund family. This suggests that it is important that we control for membership within a mutual fund family in our analysis.

As suggested by Simunic (1980), audit complexity is also potentially important in the determination of audit fees. In considering industrial firms, researchers use proxies such as the number of divisions to proxy for the degree of audit complexity. In the context of the mutual fund industry, we suspect that audit complexity may be related to two factors: (1) the frequency of trading, and (2) the use of exotic (derivative) securities. In general terms, we suspect that if a fund rarely trades, auditing that fund will be less complex than auditing a fund whose trading strategies result in frequent revisions of portfolio assets. Also, we suspect that trading strategies that involve the use of relatively complex financial securities, such as derivatives, will lead to greater audit complexity (Note 7). Thus, these arguments suggest that it is important that we control for frequency of fund trading and the use of derivative securities when examining the relation between the demand for audit certification and managerial incentives.

Simunic (1980) also suggests that certain auditees pose greater loss exposure because of the difficulty associated with confirming their assets. In the context of industrial firms, Simunic (1980) suggests that both receivables and inventories are "risky" balance sheet items because the valuation of these items is difficult. It is possible that a similar notion holds true within the context of mutual funds. In particular, it may be more difficult to confirm the value of certain types of 
assets than it is for others. As a general proposition, we expect that securities that are thinly traded or that have less price transparency will be those for which it is most difficult to confirm value. Asset liquidity and price transparency, then, are potentially important determinants of audit fees.

The potential relation between audit fees and asset liquidity and transparency suggests that it is important to control for differences in liquidity and transparency in the empirical analysis. Because we expect audit fees to be related to the liquidity of portfolio securities, we require some taxonomy of liquidity across security type. The broadest characterization is in terms of debt versus equity securities. We are wary, though, of making a blanket statement about the relative liquidity of equity and debt securities in general. For example, it may be the case that short-term government debt obligations are more liquid than equities. It may also be the case that certain debt obligations, for example, long-term corporate debt, are less liquid than equities. Because it is difficult to make a general statement with respect to the relative liquidity of debt and equity securities, we do not make a prediction about audit fees for debt and equity funds, but we do, however, control for the difference in the empirical analysis.

It is possible that there are differences in liquidity and transparency between foreign securities and domestic securities. It has been argued that foreign securities are more thinly traded and involve greater difficulty in accurate valuation than domestic securities [SEC (1992) and Solnik (1996)]. The AICPA contends that, "investments in securities of foreign issuers involve considerations not typically associated with domestic investments" [AICPA (2002)]. Among other things, the AICPA suggests that foreign securities are likely to be less liquid which, in turn, suggests that confirming foreign security values involves greater expense than confirming domestic security values. This suggests that it is important that we control for the foreign versus domestic nature of fund assets when examining the link between audit fees and managerial incentives.

It is potentially the case that portfolio liquidity is subtler than the broad classifications we suggest. For example, secondary portfolio holdings may affect liquidity and transparency. In particular, cash balances (and holdings of short-term debt securities) are likely easy to value. A foreign fund holding a large fraction of portfolio assets in the form of cash or short-term debt securities may be more liquid than a domestic equity fund holding little cash or short-term debt securities. These arguments suggest that it is important that we control for cash and short-term debt securities when examining the relation between audit fees and managerial incentives.

Also, some funds invest in what are known as restricted securities. Restricted securities are those acquired in a transaction or chain of transactions not involving a public offering [Pollock (1990)]. In the typical transaction securities are privately placed to a small number of investors. SEC rules 144 and 144A limit the resale of restricted securities (Note 8). Thus, relative to their unrestricted counterparts, restricted securities are illiquid. Given our prior arguments, we expect that funds that invest in restricted securities are likely to have higher audit fees than those funds that do not invest in restricted securities. This suggests that it is important that we control for investments in restricted securities when examining the relation between the demand for audit certification and managerial incentives.

Finally, previous research suggests that the level of audit fees may be a function of auditor reputation (or size). For example, several studies find that audit fees are a positive function of auditor reputation [DeAngelo (1981), Francis (1984), Palmrose (1986), Francis and Stokes (1986), Barber, Brooks, and Ricks (1987), Francis and Simon (1987), Rubin (1988), Craswell, Francis, and Taylor (1995)]. Simunic (1980), on the other hand, finds that audit fees decline with auditor reputation. Big-4 auditors audit $92 \%$ of our sample funds ( $99 \%$ of aggregate fund assets) (Note 9 ). We make no prediction about the relation between audit fees and auditor reputation, but we note that prior research suggests that it is potentially important that we control for auditor reputation in our empirical analysis.

\section{Sample and Preliminary Analysis}

\subsection{Sample}

Our data are from SEC investment company form N-SAR. All regulated investment companies are required to file two N-SARs annually, one covering the first six months of the fiscal year (N-SARA) and the second covering the full year (N-SARB) (Note 10). We search the SEC's EDGAR web site for all N-SARB filings during the calendar year of 2010.

We examine funds' answers to various questions on form N-SAR to determine whether a fund is closed-end or open-end, the amount of fund assets, whether a fund invests primarily in equity or debt, whether a fund invests primarily in US securities or foreign securities, the level of fund turnover (the lesser of purchases or sales divided by average net asset value), whether a fund is a member of a family of funds, the percentage of fund assets comprised of cash or cash equivalents, whether a fund traded derivatives during the reporting period (Note 11), whether a fund invested in restricted securities during the reporting period, and auditor identity. For equity funds, we collect each fund's stated primary investment objective. For debt funds, we also collect the composition of each fund's portfolio. Because they are 
unlikely to ever be closed-end, we exclude money-market funds and funds in which a majority of portfolio assets are comprised of short-term debt instruments. To be included in the final sample each fund must report each of the above data items.

Table 1 provides a description of the sample. The final sample consists of 6,543 funds- $5.6 \%$ (366) closed-end and $94.4 \%(6,177)$ open-end. Our sample funds invest primarily in equities $(77.6 \%$ of funds). Capital appreciation and growth funds represent the largest portions of equity funds. Within debt funds, government debt funds outnumber corporate debt funds (900 to 409). The overall sample is heavily weighted toward domestic funds. $86.1 \%(5,633)$ of our sample funds are domestic funds and the remaining $13.9 \%$ (910) are foreign.

\subsection{Preliminary Analysis}

Panel A of table 2 provides descriptive statistics for the level of audit fees within the mutual fund industry. The mean (median) audit fee is \$35 816 (\$29 000). Panel B of table 2 illustrates the importance of various fund characteristics in determining the level of audit fees. For example, the mean (median) audit fee for a foreign fund is $\$ 47373$ (\$38 000) while for domestic funds it is $\$ 33949$ ( $\$ 28000$ ). The difference is statistically significant and large in percentage terms. Similar relations hold along other fund dimensions. For example, funds that invest in derivatives have higher audit fees than funds that do not invest in derivatives. Also, funds that invest in restricted securities have higher audit fees than funds that do not invest in restricted securities. Panel $\mathrm{C}$ provides further evidence on the link between fund characteristics and audit fees. In panel $\mathrm{C}$ we divide funds into quartile subsamples based on various characteristics of the fund and then examine mean (median) audit fees within each subsample. As expected, audit fees are strongly related to the size of the fund being audited with average (median) fees being \$21 377 (\$18 000) for funds in the smallest size quartile and then rising monotonically to $\$ 57945$ (\$40 000) for funds in the largest fund size quartile.

Perhaps the most striking result of table 2, however, is the result with respect to fund organizational form and audit fees reported in panel B. For open-end funds the average (median) audit fee is $\$ 34488$ ( $\$ 28000$ ). For closed-end funds the average (median) audit fee is $\$ 58232$ ( $\$ 45000$ ). The difference is statistically significant and large in percentage terms. Audit fees for closed-end funds are almost two times greater than audit fees for open-end funds. This preliminary result is consistent with our hypothesis that audit fees are higher when managerial incentives are the poorer.

Of course, simple univariate comparisons implicitly hold others factors that potentially affect the level of audit fees constant. As a first step toward loosening that assumption, we examine audit fees for closed-end funds and open-end funds of various types in panel D of table 2. The results are striking. For every type of fund, audit fees for closed-end funds of that type are greater than for open-end funds of the same type. For example, among equity funds, average audit expenses are over 2.1 times greater for closed-end funds (\$71 018) than they are for open-end funds $(\$ 33053)$. A similar, though less extreme, relation holds among foreign funds. Among foreign funds the average audit expense for open-end funds is $\$ 45430$. For closed-end debt funds the average audit expense is $\$ 76474$. Regardless of which single dimension on which funds are classified, average audit fees for closed-end funds are greater than for open-end funds. These results, by fund type, provide further support for the hypothesis that when managerial incentives are poorer, funds demand higher levels of audit certification.

\section{Multivariate Analysis}

Multivariate regression results for the full sample of funds are reported in table 3. In each of our regressions we use dollar audit fees as our dependent variable. To capture potential economies of scale in the provision of audit services we include both a fund size (in dollars) and a squared fund size variable. Specifying the regressions in this manner allows for an intuitive interpretation of all the dichotomous variables. For example, the coefficient on the closed-end fund variable captures the difference in audit fees for a closed-end fund versus an open-end fund (Note 12).

Our results are consistent with those of the univariate analysis and suggest that audit fees are greater when managerial incentives are poorer. For example, in the first regression of table 3 we report that audit fees are $\$ 22739$ more for closed-end funds than for open-end funds. Again, the difference is not only statistically significant $(\mathrm{t}$-stat $=14.02)$, but also large relative to total audit fees. We conclude that this result on mutual fund organizational form and audit fees is consistent with our hypothesis that when managerial incentives are poorest, audit fees are greatest.

As noted previously, prior research finds that manipulation or misrepresentation of accounting measures increases as the sensitivity of manager wealth to firm value increases. We follow Coles, Suay, and Woodbury (2000) and Deli (2002) and define the advisor's sensitivity to fund value (i.e., the advisor's marginal compensation rate) as the change in advisor compensation given a small change in fund assets (as indicated by the fund advisory contract). For example, suppose a fund's advisory contract calls for an advisor to receive $1 \%$ of fund assets under $\$ 500$ million, $0.75 \%$ of fund assets greater than $\$ 500$, but less than $\$ 1$ billion, and $0.5 \%$ of fund assets greater than $\$ 1$ billion. Also, assume that the fund has 
$\$ 600$ million of assets. In that case, we assign a value of $0.75 \%$ to the advisor's marginal compensation rate. If the propensity of fund managers to misrepresent fund value is a function of the sensitivity of advisor wealth to changes in fund value, then we expect that audit fees will be positively related to marginal compensation rates. We examine that possibility in the second and third columns of table 3.

In the second column of table 3 we include the advisor marginal compensation rate by itself. When we do so, we find that the relation between audit fees and marginal compensation rates is positive and statistically significant ( $\mathrm{t}$-stat $=3.73$ ). Audit fees increase with marginal compensation rates. This result confirms our expectation that when managerial incentives are poor audit fees will be greater.

We next include the marginal compensation rate plus a term interacting the marginal compensation rate with fund organizational form. There are three results that are important to note. First, the coefficient on marginal compensation remains statistically significant. All funds, whether closed-end or open-end, pay higher audit fees if they have higher marginal compensation rates. Second, the interaction between the closed-end indicator and marginal compensation is significantly positive. The effect of marginal compensation rates on audit fees is greater for closed-end funds than for open-end funds. In other words, the effect of marginal compensation is magnified in the (relatively) poor contracting environment of closed-end funds. Finally, we note that the closed-end fund indicator variable becomes insignificant with the inclusion of marginal compensation and its interaction with fund organizational form. That result suggests that it is not just the closed-end form, itself, that creates a problem, but the closed-end form in combination with other arrangements (that are themselves, the manifestation of poor contracting).

Excess fund expenses offer another means by which to examine the link between audit fees and managerial incentives. We do so by including an estimate of excess expenses in our analysis. We implement the test by first regressing expense ratios (net of the audit fee) on the log of fund size and a set of dummy variables capturing fund organizational form and fund type. We then take the residuals from that regression as our measure of "excess" expenses. We include the residuals in our regression analysis and report the results in the fourth column of table 3 . We find that audit fees are positively related ( $t$-stat $=9.41)$ to excess expenses. If our measure of excess expenses is an accurate proxy for poor managerial incentives, then the results suggest that audit fees are greater when managerial incentives are poorest.

The fee structures of open-end funds offer another means of providing indirect evidence on the link between managerial incentives and audit fees. Chordia (1996) argues that open-end funds use back-end fees to make redemption prohibitively costly. Like closed-end funds relative to open-end funds, open-end funds using back-end fees face less of a disciplining force from redemptions than open-end funds without back-end fees. We make use of the difference in incentives that this creates by repeating our analysis within the subsample of open-end funds while including a dichotomous variable for the use of back-end fees (Note 13). The back-end fee variable, then, operates in the same way as our closed-end variable in that it captures differences in managerial incentives. Consistent with our results for closed-end funds, we find that funds making use of back-end fees have significantly higher audit fees ( $1 \%$ level). Specifically, open-end funds using back-end fees have audit fees that are $\$ 3,839$ greater than open-end funds without back-end fees. Thus, we consider this evidence on the use of back-end fees and audit fees as further indirect evidence consistent with our earlier results.

Results for our control variables are also consistent with the univariate analysis. For example, foreign funds have higher audit fees than domestic funds. In the four regressions of Table 3 foreign fund audit fees are between $\$ 8,623$ and $\$ 10$ 519 higher than for domestic funds. A similar relation holds for those funds investing in derivatives relative to those not investing in derivatives. Funds investing in derivatives have audit fees that are between $\$ 4,549$ and $\$ 5,801$ higher than funds that do not invest in derivatives (the difference is statistically significant at the $1 \%$ level). Likewise, funds that invest in restricted securities have audit fees that are between $\$ 5,340$ and $\$ 8,250$ higher than funds that do not invest in restricted securities (again, the difference is statistically significant at the $1 \%$ level). Also consistent with expectations, audits fees appear to experience both economies of scale (as captured in the two fund size coefficients) and scope (as captured by the family size coefficients).

In sum, we capture variation in managerial incentives several ways. Regardless of the means by which we capture managerial incentives, we find that audit fees are greater when managerial incentives are poorest. Also, audit fees in the mutual fund industry appear to be affected by factors previously documented to affect the audit fees of industrial firms. Overall, our results are consistent with the hypothesis that audit fees are affected by managerial incentives.

\section{Additional Analysis}

The above results are consistent with the hypothesis that audit fees are related to managerial incentives. One potential limitation of that analysis stems from its reliance on a coarse characterization of fund assets (at least in terms of their 
debt v. equity characteristics). We now address that limitation by controlling for finer characterizations of fund assets within the equity and debt subsamples of our funds. We then examine the possibility that audit fees, themselves, are a manifestation of managerial opportunism. We then conduct sensitivity analysis to make sure our results are not specific to our regression specifications.

\subsection{Equity funds}

To further explore the link between managerial incentives and audit fees we examine that relation in the context of equity funds while controlling for each fund's primary investment objective. Form N-SAR requires equity funds to classify their primary investment objective as: (1) aggressive capital appreciation, (2) capital appreciation, (3) growth, (4) growth and income, (5) total return, or (6) income. We examine the link between organizational form and audit fees among equity funds while controlling for investment objective in panel A of table 4 (Note 14). We include a dummy variable for each of the investment objectives except aggressive capital appreciation.

The results reported in Panel A of table 4 suggest that our previous results using the full sample of funds are not driven by an overly coarse characterization of our sample funds. For example, while controlling for equity fund investment objective, we continue to find that closed-end funds have higher audit fees than their open-end fund counterparts $(1 \%$ level). Again, the relation is large in percentage terms as well as statistically significant. Among equity funds, closed-end funds have audit fee that are $\$ 37407$ higher than similar open-end funds. Also, audit fees remain positively related to excess fees ( $1 \%$ level) as does the coefficient on marginal compensation. We interpret these equity subsample results as providing further evidence consistent with our hypothesis that when managerial incentives are poor, audit fees are higher.

\subsection{Debt funds}

To provide further evidence on the link between managerial incentives and audit fees we also examine the subsample of debt funds. Unlike the case of equity funds where we only have data on funds' stated investment objectives, form $\mathrm{N}$-SAR filings for debt funds allow us to observe the actual level of investment in different types of debt. We characterize each debt fund by the type of debt that makes up the largest fraction of portfolio assets. Results are reported in panel B of table 4.

In the first row of panel B we report results for the full subsample of debt funds while controlling for whether funds invest in corporate or government debt. Consistent with our results using the full sample and our results using the equity subsample, closed-end debt funds have significantly higher audit fees than their open-end fund counterparts (1\% level). The difference remains large in percentage terms as well. Closed-end debt fund audit fees are $\$ 10091$ higher than their open-end debt fund counterparts. In the second regression of panel B, we see that the coefficient on the interaction term between closed-end and advisor marginal compensation is significantly positive ( $1 \%$ level $)$ as in the full sample analysis. Among closed-end bond funds, as advisor marginal compensation rates rise, audit fees increase. Finally, in the third regression of panel $\mathrm{B}$, we continue to find that audit fees are positively related to excess expenses. Overall, the results within the debt subsample, then, are consistent with those for the full sample.

In panel $\mathrm{C}$ we examine the relation between organizational form and audit fees for the subsample of funds comprised of funds that invest in government securities. There are three broad classes of government debt that funds invest in: (1) US Treasury debt, (2) agency debt, and (3) municipal debt. We control for the type of government debt by including a dummy variable for agency debt and municipal debt. The interaction term for marginal compensation and fund organizational form remains significantly positive ( $1 \%$ level). Also, audit fees remain positively related to excess expenses ( $1 \%$ level). Overall, the results using the subsample of debt funds are broadly consistent with our initial results using the full sample of funds and suggest they were not driven by an overly coarse characterization of the funds.

\subsection{Managerial Opportunism}

It is possible that rather than reflecting equilibrium outcomes, higher audit fees among closed-end funds are actually a manifestation of an agency conflict between investors and fund advisors. John Bogle, founder and former CEO of the Vanguard family of mutual funds, suggests that there is an inherent conflict of interest in the mutual fund industry because the firms that audit mutual funds also tend to be the ones that audit the fund advisor. This opens the door to the possibility that the costs of auditing the fund advisor could be shifted to the funds that the fund advisor manages (Note 15). Bogle makes his comment with regard to the mutual fund industry in general, but there is reason to believe that the problem could be most severe for closed-end funds. To the extent that the disciplining mechanism of constant redemption is unavailable to closed-end fund investors and to the extent that fund advisors want to shift auditing expenses from themselves to the funds they manage, it may make sense that fund advisors shift audit expenses onto their closed-end funds. Large fund managers are likely to have greater dollar audit expenses to shift than small fund managers. 
If families of funds tend to be managed, in whole or in substantial part, by one fund advisor, then it seems reasonable to assume that fund family size proxies for the amount of audit expense dollars that could be shifted from the fund advisor to its funds. If, by virtue of their poorer incentives, fund advisors shift all (or at least a disproportionate share) of their audit expense to their closed-end funds, then we would expect closed-end funds that are members of large fund families to have higher audit fees. Although is seems unlikely that such an arrangement could survive in a competitive equilibrium, we address that possibility by interacting our organizational form variable with our family size variable. In un-tabulated results, we find that when closed-end funds are members of large fund families they actually have lower audit fees (1\% level). We interpret this result as evidence that is inconsistent with the difference in audit fees for closed-end funds and open-end funds being a manifestation of an agency problem between funds and their advisors.

Another possibility is that fund managers may have some ability to "allocate" audit fees across the funds they manage. If that is the case, then fund managers might, for example, allocate expenses away from poorly performing funds as a means of increasing performance. We find that possibility unlikely with respect to audit fees because mutual funds are separate legal entities and the non-interested directors on a mutual fund's board have an obligation to ensure that each fund's interests are not being compromised to the benefit of another fund [Glazer (1970) and Nutt (1971)]. Nevertheless, we allow for the possibility by examining the relation between net fund flows and audit fees among open-end funds. Managerial opportunism suggests funds experiencing outflows should have lower audit expenses (as managers attempt to improve performance in order to stem the outflow).

To test that possibility we repeat our empirical analysis for the subsample of open-end funds while controlling for net flows (Note 16). Contrary to the implications of managerial opportunism, we find a negative and statistically significant ( $1 \%$ level) relation between net flows and audit fees. Funds experiencing outflows pay higher audit fees and funds experiencing inflows pay lower fees. One explanation for the difference is that audit fees are, at least to some extent, pre-negotiated and the negative coefficient captures the lag between changes in fund size (as a function of net cash flows) and negotiated audit fees. We note that our results pertain to the potential allocation of audit fees among open-end funds because only open-end funds experience net flows in and out of the funds. Thus, we interpret this result as indirect evidence that is inconsistent with audit fees being a manifestation of advisor opportunism rather than representing an equilibrium price for audit certification.

\subsection{Additional Empirical Analysis}

It is possible that our results are a function of outliers in the data. We allow for the possibility in two ways. First, we repeat our analysis using rank regressions. Specifically, we create ranks for audit fees and repeat our analysis. Our inferences remain essentially the same. The one exception is the coefficient on the interaction between closed-end fund and advisor marginal compensation which remains positive, but becomes statistically insignificant. Second, we use the natural log of audit fees and fund size. Again, our inferences are unchanged.

A second possible limitation of our analysis stems from our choice of sample period. We examine only one year of cross-sectional data (i.e., funds filing in 2010). While our full sample size suggests that power is not as issue, our results could be driven by the particular sample year. Given the relative stability of auditing relationships we do not expect this to be a problem. To address the possibility, however, we collect data for funds filing in 2002 and repeat our analysis. Our results are unaffected. For example, the mean (median) audit fees for closed-end funds in 2002 is $\$ 48615$ (\$41 500). The comparable number for open-end funds is $\$ 23318$ (\$18 000). When looking at the subsample of equity funds, closed-end equity funds have mean (median) audit fees of \$49 471 (\$47 000) whereas open-end equity funds have mean (median) audit fees of \$23 332 (\$17 000). When looking at the subsample of debt funds, closed-end debt funds have mean (median) audit fees of $\$ 43528$ (\$38 000) whereas open-end equity funds have mean (median) audit fees of $\$ 22$ $632(\$ 19000)$. All of these differences in means and medians are statistically significant at the $1 \%$ level. We conclude, therefore, that our results are not merely a byproduct of looking at a particular year.

\section{Conclusion}

We examine the relation between audit fees and managerial incentives in the mutual fund industry. Using proxies for managerial incentives based on fund organizational form, advisory firm compensation, and fund expenses, we find that audit fees are greater when advisor incentives are poorest. In particular, we find that closed-end funds have significantly higher audit fees than their open-end fund counterparts. The difference is large in percentage terms as well as statistically significant, with closed-end funds having audit fees that are essentially twice the level of audit fees for open-end funds. We also find that audit fees are greater for closed-end fund advisors with higher levels of marginal compensation. That result is consistent with recent research suggesting that managerial incentives to manipulate or misrepresent accounting numbers are positively related to the sensitivity of managerial wealth to firm value. Finally, we find that audit fees are positively related to excess fund expenses. Recent research suggests that (positive) excess 
expenses are consistent with an environment of poor managerial incentives. Thus, the results on excess fund expenses also confirm the relation between audit fees and managerial incentives. Overall, the results suggest that managerial incentives play an important role in determining audit fees.

\section{References}

Abbot, L., Parker S., Peters, G., \& Raghunandan, K. (2003). The association between audit committee characteristics and audit fees, Auditing: A Journal of Practice and Theory, 22, 17-32.

Admati, A., \& Pfleiderer, P. (1997). Does it all add up? Benchmarks and the compensation of active portfolio managers, Journal of Business, 70, 323-350. http://dx.doi.org/10.1086/209721

American Institute of Certified Public Accountants. (2002). Audits of Investment Companies, (New York, NY).

Barber, W., Brooks, E., \& Ricks, W. (1987). An empirical investigation of the market for audit services in the public sector, Journal of Accounting Research, 25, 216-239.

Barclay, M., Holderness, C., \& Pontiff, J. (1993). Private benefits from block ownership and discounts on closed-end funds, Journal of Financial Economics, 33, 263-291. http://dx.doi.org/10.1016/0304-405X(93)90008-Y

Bell, T., Landsman, W., \& Shackelford, D. (2001). Auditors' perceived business risk and audit fees: Analysis and evidence, Journal of Accounting Research, 39, 35-43. http://dx.doi.org/10.1111/1475-679X.00002

Bergstresser, D., \& Philippon, T. (2006). CEO incentives and earnings management, Journal of Financial Economics, 80, 511-529. http://dx.doi.org/10.1016/j.jfineco.2004.10.011

Braur, G. (1984). 'Open-ending' closed-end funds, Journal of Financial Economics, 13, 491-507. http://dx.doi.org/10.1016/0304-405X(84)90012-6

Burns, N., \& Kedia, S. (2006). The impact of performance-based compensation on misreporting, Journal of Financial Economics, 79, 35-67. http://dx.doi.org/10.1016/j.jfineco.2004.12.003

Carcello, J., Hermanson, D., Neal, T., \& Riley, R., Jr. (2002). Board characteristics and audit fees, Contemporary Accounting Research, 19, 365-384. http://dx.doi.org/10.1506/CHWK-GMQ0-MLKE-K03V

CDA/Wiesenberger. (2001). Investment Companies Yearbook 2000, CDA Investment Technologies (Rockville, MD).

Chen, H., Chung, H., \& Wynn, J. (2009). Does incentive-based compensation impair independence of internal auditors? Evidence from audit fees, working paper, Arizona State University.

Cheng, Q., \& Warfield, T. (2005). Equity incentives and earnings management, The Accounting Review, 80, 441-476. http://dx.doi.org/10.2308/accr.2005.80.2.441

Chow, C. (1982). The demand for external auditing: Size, debt and ownership influences, The Accounting Review, 57, 272-291.

Chordia, T. (1996). The structure of mutual fund charges, Journal of Financial Economics, 41, 3-39. http://dx.doi.org/10.1016/0304-405X(95)00856-A

Clarkson, P., \& Simunic, D. (1994). The association between audit quality, retained ownership, and firm-specific risk in U.S. and Canadian IPO markets, Journal of Accounting and Economics, 17, 207-228. http://dx.doi.org/10.1016/0165-4101(94)90010-8

Cohen, D., Dey, A., \& Lys, T. (2008). Real and accrual-based earnings management in the pre- and post-Sarbanes-Oxley periods, The Accounting Review, 83, 757-787. http://dx.doi.org/10.2308/accr.2008.83.3.757

Coles, J., Suay, J., and Woodbury, D. (2000). Fund advisor compensation in closed-end funds, Journal of Finance 55, 1385-1414. http://dx.doi.org/10.1111/0022-1082.00251

Cornett, M., Marcus, A., \& Tehranian, H. (2008). Corporate governance and pay-for-performance: The impact of earnings management, Journal of Financial Economics, 87, 357-373. http://dx.doi.org/10.1016/j.jfineco.2007.03.003

Coulton, J., Craswell, A., \& Taylor, S. (2001). Do board characteristics influence audit fees?, Working paper, University of Technology, Sydney.

Craswell, A., Francis, J., \& Taylor, S. (1995). Auditor brand name reputations and industry specialization, Journal of Accounting and Economics, 20, 297-322. http://dx.doi.org/10.1016/0165-4101(95)00403-3

Datar, S., Feltham, G., \& Hughes, J. (1991). The role of audits and audit quality in valuing new issues, Journal of Accounting and Economics, 14, 3-49. http://dx.doi.org/10.1016/0167-7187(91)90057-R

Davis, L., Ricchiute, D., \& Trompeter, G. (1993). Audit effort, audit fees, and the provision of nonaudit services to audit 
clients, The Accounting Review, 68, 135-150.

Defond, M. (1992). The association between changes in client firm agency costs and auditor switching, Auditing: A Journal of Practice and Theory, 11, 16-31.

Del Guercio, D., Dann, L., \& Partch, M. (2003). Governance and boards of directors in closed-end investment companies, Journal of Financial Economics, 69, 111-152. http://dx.doi.org/10.1016/S0304-405X(03)00110-7

Deli, D. (2002). Mutual fund advisory contracts: An empirical investigation, Journal of Finance, 57, 109-133. http://dx.doi.org/10.1111/1540-6261.00417

Deli, D., \& Varma, R. (2002). Closed-end versus open-end: The choice of organizational form, Journal of Corporate Finance, 8, 1-27. http://dx.doi.org/10.1016/S0929-1199(01)00038-4

DeAngelo, L. (1981). Auditor size and audit quality, Journal of Accounting and Economics, 3, 189-199. http://dx.doi.org/10.1016/0165-4101(81)90002-1

Edelen, R. (1999). Investor flows and the assessed performance of open-end mutual funds, Journal of Financial Economics, 53, 439-466. http://dx.doi.org/10.1016/S0304-405X(99)00028-8

Efendi, J., Srivastava, A., \& Swanson, E. (2007). Why do corporate managers misstate financial statements? The role of option compensation and other factors, Journal of Financial Economics, 85, 667-708. http://dx.doi.org/10.1016/j.jfineco.2006.05.009

Erickson, M., Hanlon, M., \& Maydew, E. (2006). Is there a link between executive compensation and accounting fraud?, Journal of Accounting Research, 44, 113-143. http://dx.doi.org/10.1111/j.1475-679X.2006.00194.x

Fama, E., \& Jensen, M. (1983a). Agency problems and residual claims, Journal of Law and Economics, 26, 327-349. http://dx.doi.org/10.1086/467038

Fama, E., \& Jensen, M. (1983b). Separation of ownership and control, Journal of Law and Economics, 26, 301-325. http://dx.doi.org/10.1086/467037

Feltham, G., Hughes, J., \& Simunic, D. (1991). Empirical assessment of the impact of auditor quality on the valuation of new issues, Journal of Accounting and Economics, 14, 375-399. http://dx.doi.org/10.1016/0165-4101(91)90009-D

Firth, M. (1985). An analysis of audit fees and their determinants in New Zealand, Auditing: A Journal of Practice \& Theory, 4, 23-37.

Francis, J. (1984). The effect of audit firm size on audit prices: A study of the Australian market, Journal of Accounting and Economics, 6, 133-157. http://dx.doi.org/10.1016/0165-4101(84)90010-7

Francis, J., \& Simon, D. (1987). A test of audit pricing in the small-client segment of the U.S. audit market, The Accounting Review, 62, 145-157.

Francis, J., \& Stokes, D. (1986). Audit prices, product differentiation, and scale economies: Further evidence from the Australian audit market, Journal of Accounting Research, 24, 383-393. http://dx.doi.org/10.2307/2491141

Francis, J., \& Wilson, E. (1988). Auditor changes: A joint test of theories relating to agency costs and auditor differentiation, The Accounting Review, 63, 663-682.

Gao, P., \& Shrieves, R. (2002). Earnings management and executive compensation: a case of overdose of option and underdose of salary?, working paper, University of Tennessee.

Glazer, D. (1970). A study of mutual fund complexes, University of Pennsylvania Law Review, 119, $205-282$. http://dx.doi.org/10.2307/3311247

Grinblatt, M., \& Titman, S. (1989). Adverse risk incentives and the design of performance-based contracts, Management Science, 35, 807-822. http://dx.doi.org/10.1287/mnsc.35.7.807

Heinkel, R., \& Stoughton, N. (1994). The dynamics of portfolio management contracts, Review of Financial Studies, 7 , 351-387. http://dx.doi.org/10.1093/rfs/7.2.351

Hogan, C, \& Wilkins, M. (2008). Evidence on the audit risk model: Do auditors increase audit fees in the presence of internal control deficiencies?, Contemporary Accounting Research, 25, 219-242. http://dx.doi.org/10.1506/car.25.1.9

Jensen, M., \& Meckling, W. (1976). Theory of the firm: Managerial behavior, agency costs and ownership structure, Journal of Financial Economics, 3, 305-360. http://dx.doi.org/10.1016/0304-405X(76)90026-X

Johnson, S., Ryan, H., \& Tian, Y. (2009). Managerial incentives and corporate fraud: The sources of incentives matter, Review of Finance, 13, 115-145. http://dx.doi.org/10.1093/rof/rfn014 
Koski, J., \& Pontiff, J. (1999). How are derivatives used? Evidence from the mutual fund industry, Journal of Finance, 54, 791-816. http://dx.doi.org/10.1111/0022-1082.00126

Kuang, Y. (2008). Performance-vested stock options and earnings management, Journal of Business Finance \& Accounting, 35, 1049-1078. http://dx.doi.org/10.1111/j.1468-5957.2008.02104.x

Lee, C., Shleifer, A., \& Thaler, R. (1991). Investor sentiment and the closed-end fund puzzle, Journal of Finance, 46, 76-110. http://dx.doi.org/10.2307/2328690

Low, L., Tan, P., \& Koh, H. (1990). The determinants of audit fees: An analysis in the Singapore context, Journal of Business Finance \& Accounting, 17, 285-295. http://dx.doi.org/10.1111/j.1468-5957.1990.tb00561.x

Malkiel, B. (1977). The valuation of closed-end investment company shares, Journal of Finance, 32, 847-858. http://dx.doi.org/10.2307/2326318

Nutt, W. (1971). A study of mutual fund independent directors, University of Pennsylvania Law Review, 120, 179-270. http://dx.doi.org/10.2307/3311369

O'Keefe, T., Simunic, D., \& Stein, M. (1994). The production of audit services: Evidence from a major public accounting firm, Journal of Accounting Research, 32, 241-261. http://dx.doi.org/10.2307/2491284

Palmrose, Z. (1984). The demand for quality-differentiated audit services in an agency-cost setting: An empirical investigation, in Proceedings of the Sixth Symposium on Auditing Research, edited by A.R. Abdel-Kahlik and I. Solomon, University of Illinois Press, Champaign, 229-252.

Palmrose, Z. (1986). Audit fees and auditor size: Further evidence, Journal of Accounting Research, 24, 97-110. http://dx.doi.org/10.2307/2490806

Peng, L., \& Roell, A. (2005). Executive pay, earnings manipulation, and shareholder litigation, working paper, Baruch College.

Pollock, M. (1990). Resales of Restricted Securities Under SEC Rules 144 and 144A, The Bureau of National Affairs, Inc. (Washington, DC).

Richardson, S., Tuna, I., \& Wu, M. (2003). Capital market pressures and earnings management: The case of earnings restatements, working paper, University of Pennsylvania.

Rubin, M. (1988). Municipal audit fee determinants, The Accounting Review, 63, 219-236.

Simon, D., \& Francis, J. (1988). The effects of auditor change on audit fees: Tests of price cutting and price recovery, The Accounting Review, 63, 255-269.

Simunic, D. (1980). The pricing of audit services: Theory and evidence, Journal of Accounting Research, 18, 161-190. http://dx.doi.org/10.2307/2490397

Solnik, B. (1996). International Investments, Addison-Wesley Publishing Company (Reading, MA).

Starks, L. (1987). Performance incentive fees: An agency theoretic approach, Journal of Financial and Quantitative Analysis, 22, 17-32. http://dx.doi.org/10.2307/2330867

Stoughton, N. (1993). Moral hazard and the portfolio management problem, Journal of Finance, 48, 2009-2028. http://dx.doi.org/10.2307/2329079

Tufano, P., \& Sevick, M. (1997). Board structure and fee-setting in the U.S. mutual fund industry, Journal of Financial Economics, 46, 321-356. http://dx.doi.org/10.1016/S0304-405X(97)00033-0

Turpen, R. (1990). Differential pricing on auditors' initial engagements: Further evidence, Auditing: A Journal of Practice and Theory, 9, 60-76.

United States Securities and Exchange Commission, Division of Investment Management. (1992). Protecting Investors: A Half Century of Investment Company Regulation, Washington DC.

Watts, R. \& Zimmerman, J. (1986). Positive Accounting Theory, Prentice-Hall (Englewood Cliffs, New Jersey).

Zitzewitz, E. (2003). Who cares about shareholders? Arbitrage-proofing mutual funds, Journal of Law, Economics, \& Organization, 19.2, 245-280. http://dx.doi.org/10.1093/jleo/ewg011

Zweig, M. (1973). An investor expectations stock price predictive model using closed-end fund premiums, Journal of Finance, 28, 67-78. http://dx.doi.org/10.2307/2978169 


\section{Notes}

Note 1. Other studies return to the demand side-examining audit fees (as a proxy for demanded audit quality) and corporate governance [Abbot, Parker, Peters, and Raghunandan (2003), Carcello, Hermanson, Neal, and Riley (2002), and Coulton, Craswell, and Taylor (2001)]. Those studies show a link between audit committee composition and the level of audit fees and between board independence, activity, and expertise and audit fees. See Abbot, Parker, Peters, and Raghunandan (2003) on the relation between audit committees and audit fees and Carcello, Hermanson, Neal, and Riley (2002) and Coulton, Craswell, and Taylor (2001) for the relation between full board independence, activity, and expertise and the level of audit fees.

Note 2. Barclay, Holderness, and Pontiff (1993) find evidence consistent with meaningful agency conflicts between closed-end fund investors and fund managers.

Note 3. Other objectives include determining whether: (1) the fund has ownership of and accounting control over all of its portfolio investments, (2) transactions are authorized and recorded in the proper account, amount, and period, (3) income from investments and realized gains and losses from securities transactions are properly accounted for, and (4) investments are free of liens, pledges, or other security interests or, if not, such matters are properly identified and disclosed [AICPA (2002)].

Note 4. For example, if a pricing service uses matrix pricing to determine fair value, the auditor should: (1) review the matrix used, (2) determine that the results have been review for reasonableness, and (3) compare sales proceeds from securities sold during the year to the value used on several days before the sale [AICPA (2002)].

Note 5. The experience of two open-end bond funds managed by Heartland Advisors is consistent with this notion. In October of 2000 Heartland wrote down the value of its High-Yield Municipal Bond fund by $70 \%$ and the value of its Short Duration High-Yield Municipal Fund by $44 \%$. Both funds had been experiencing net withdrawals driven by earlier, but much smaller write-downs of fund assets. Heartland had been meeting those redemptions by drawing down lines of credit supplied by Deutshe Bank AG. In the face of continued redemptions and the need to sell portfolio assets to meet those redemptions, Heartland was forced to write down portfolio assets to their true values. Closed-end funds, by construction, would never face the same necessity of writing down fund values because they do not have to service redemptions. It seems likely, given the above example, that misvaluations are more likely in closed-end funds than in open-end funds.

Note 6. Simunic (1980) suggests two additional factors that determine the level of audit fees, but that are not relevant in the context of our study within the mutual fund industry: (1) the industry of the auditee, and (2) whether the auditee is publicly traded.

Note 7. Koski and Pontiff (1999) find that funds use derivatives as a means of adjusting portfolio exposure rather than trading the underlying assets.

Note 8. In particular, Rule 144 prohibits the resale of restricted securities if the issue is less than two years old. Rule 144A removes that constraint conditional on the purchaser being a qualified institutional buyer.

Note 9. Deloitte Touche audits 986 (15.1\%) of our sample funds, Ernst Young 1,383 (21.1\%), KPMG 941 (14.4\%), and PriceWaterhouseCoopers 2,703 (41.3\%).

Note 10. The SEC is authorized under Section 30(b) of the Investment Company Act of 1940 and Sections 13 and 15(d) of the 1934 Act to solicit information required by form N-SAR. Disclosure of the information specified on form N-SAR is mandated under SEC Rule 30b1-1 (Semi-Annual Report for Registered Management Investment Companies) Audit fees are an explicit line item included on form N-SAR.

Note 11. Funds answer the following six questions with respect to investments in equity and debt derivatives: (1) did the fund write or invest in options on equities?, (2) did the fund write or invest in options on stock indices?, (3) did the fund write or invest in stock index futures?, (4) did the fund write or invest in options on stock index futures?, (5) did the fund write or invest in options on debt securities?, and (6) did the fund write or invest in interest rate futures? If a fund answers "yes" to at least one of these six questions then we classify it as investing in derivatives.

Note 12. In order to make sure that we our results are not driven by the specification of our regressions, we repeat our analysis using ranks of the left-hand-side and right-hand-side variables as well as using logs of both audit fees and fund size (see section 5.iv). Our inferences with respect to the audit fees of closed-end funds are unaffected.

Note 13. Specifically, the variable takes the value of one if a fund charges either a contingent deferred sales charge or a redemption fee.

Note 14. Because equity derivatives are likely to be the relevant derivatives for equity funds, we control for investment in equity derivatives (rather than any derivative) during the reporting period.

Note 15. "Do mutual funds have auditing conflicts?," The Wall Street Journal, March 14, 2002.

Note 16. Open-end funds report gross flows for six months on form N-SARB. 
Table 1. Sample Description

\begin{tabular}{lc}
\hline Fund Type: & Number (\% of sample) \\
Full Sample & 6,543 \\
Closed-end & $366(5.6)$ \\
Open-end & $6,177(94.4)$ \\
& \\
Equity & $5,075(77.6)$ \\
Aggressive Capital Appreciation & $202(3.1)$ \\
Capital Appreciation & $2,175(33.2)$ \\
Growth & $1,241(19.0)$ \\
Growth and Income & $578(8.8)$ \\
Income & $139(2.1)$ \\
Total Return & $740(11.3)$ \\
& $1,468(22.4)$ \\
Debt & $900(13.8)$ \\
Government & $77(1.2)$ \\
L-T Treasury & $170(2.6)$ \\
L-T Agency & $653(10.0)$ \\
L-T Municipal & $409(6.3)$ \\
Corporate & $910(13.9)$ \\
Foreign & $5,633(86.1)$ \\
Domestic & \\
&
\end{tabular}

Our data are from the SEC's Electronic Data Gathering and Retrieval (EDGAR) world wide web site. The source is investment company form N-SARB for those funds that filed such a form during the calendar year 2010. We examine funds' answers to various questions on form N-SAR to determine whether a fund invests primarily in equity or debt. For equity funds we collect each fund's stated primary investment objective. For debt funds we collect the composition of each fund's portfolio. Debt funds are classified by what type of debt makes up the single largest percentage of portfolio assets. 
Table 2. Univariate analysis of audit expense

\begin{tabular}{ccccccc}
\hline \multicolumn{7}{c}{ Panel A: Descriptive statistics for audit expense } \\
Mudit Fees & Mean & Median & Max. & $75^{\text {th }}$ Perc. & $25^{\text {th }}$ Perc. & Min. \\
\cline { 2 - 7 } & 35816 & 29000 & 587000 & 43000 & 18000 & 1,000 \\
\hline \multicolumn{7}{c}{} \\
\cline { 2 - 6 }
\end{tabular}

Panel B: Mean (median) audit expense by fund type.

\begin{tabular}{lccc} 
& Yes & No & $\begin{array}{c}\text { t-statistic for difference in means } \\
\text { Z-statistic for diff. in medians) }\end{array}$ \\
\cline { 2 - 4 } Closed-end & 58232 & 34488 & $8.19^{* *}$ \\
fund? & $(45000)$ & $(28000)$ & $(10.52)^{* *}$ \\
Equity fund? & 34294 & 41076 & $-6.82^{* *}$ \\
& $(28000)$ & $(34000)$ & $(-8.87)^{* *}$ \\
Foreign fund? & 47373 & 33949 & $10.62^{* *}$ \\
& $(38000)$ & $(28000)$ & $(13.10)^{* *}$ \\
Derivatives? & 40981 & 33971 & $7.26^{* *}$ \\
Restricted & $(33000)$ & $(28000)$ & $(8.66)^{* *}$ \\
Securities? & 48500 & 31791 & $14.58^{* *}$ \\
Big-5? & $(37000)$ & $(26000)$ & $(14.89)^{* *}$ \\
& 37322 & 18725 & $20.34^{* *}$ \\
& $(30000)$ & $(15000)$ & $(18.61)^{* *}$
\end{tabular}

\begin{tabular}{|c|c|c|c|c|c|c|}
\hline & \multicolumn{6}{|c|}{ Panel C: Mean (median) audit expense by quartile ranking of each explanatory variable $\left(1=\right.$ smallest). ${ }^{\text {a }}$} \\
\hline & 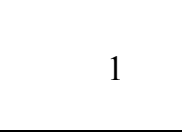 & 2 & 3 & 4 & $\begin{array}{l}\text { Kruskal- } \\
\text { Wallis } \\
\text { (p-value) }\end{array}$ & $\begin{array}{c}\text { Spearman } \\
\text { correlation } \\
\text { (p-value) }\end{array}$ \\
\hline Fund Size & $\begin{array}{c}21377 \\
(18000)\end{array}$ & $\begin{array}{c}30745 \\
(28000)\end{array}$ & 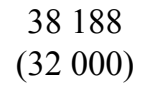 & $\begin{array}{c}52945 \\
(40000)\end{array}$ & $\begin{array}{l}1297.8 \\
(.001)\end{array}$ & $\begin{array}{c}.462 \\
(.001)\end{array}$ \\
\hline Family Size & $\begin{array}{c}28573 \\
(15000)\end{array}$ & $\begin{array}{c}32588 \\
(17000)\end{array}$ & $\begin{array}{c}39171 \\
(19000)\end{array}$ & $\begin{array}{c}42875 \\
(28000)\end{array}$ & $\begin{array}{l}546.6 \\
(.001)\end{array}$ & $\begin{array}{l}.298 \\
(.001)\end{array}$ \\
\hline Turnover & $\begin{array}{c}32053 \\
(25000)\end{array}$ & $\begin{array}{c}36651 \\
(29000)\end{array}$ & $\begin{array}{c}38186 \\
(30000)\end{array}$ & $\begin{array}{c}36391 \\
(30000)\end{array}$ & $\begin{array}{c}60.9 \\
(.001)\end{array}$ & $\begin{array}{c}.079 \\
(.001)\end{array}$ \\
\hline Cash & $\begin{array}{c}29301 \\
(24000)\end{array}$ & $\begin{array}{c}39970 \\
(33000)\end{array}$ & $\begin{array}{c}38037 \\
(32000)\end{array}$ & $\begin{array}{c}36584 \\
(28000)\end{array}$ & $\begin{array}{l}214.1 \\
(.001)\end{array}$ & $\begin{array}{c}.061 \\
(.001)\end{array}$ \\
\hline
\end{tabular}

The sample consists of 6,543 open-end and closed-end funds that filed annual N-SARs with the SEC in 2010. Closed-end is a dichotomous variable that is true if a fund closed-end and false if it is open-end. Equity fund is a dichotomous variable that is true if a fund invests primarily in equity securities and false if it invests primarily in debt securities. Foreign fund is a dichotomous variable that is true if a fund invests primarily in foreign securities and false if it invests primarily in domestic securities. Member of a family of funds is a dichotomous variable that is true if a fund is a member of a family of mutual funds and false if it is not. Derivatives is a dichotomous variable that is true if a fund invests in derivative securities and false if it does not. Restricted securities is a dichotomous variable that is true if a firm invests in restricted securities and false if it does not. Big-5 is a dichotomous variable equal that is true if the auditor is a Big-5 auditor and false if it is not. Fund size is total fund net assets. Family size is the total (within sample) net assets of the fund family. Turnover is the lesser of fund purchases or sales divided by average net assets value. Cash is the percentage of cash relative to total fund assets. For continuous variables in panel $\mathrm{C}$ we create subsamples based on quartile rankings of the variable and calculate means and medians within quartile subsamples. ${ }^{* *}$ indicates significance at the $1 \%$ level. ${ }^{*}$ indicates significance at the $5 \%$ level. 
Table 2. Univariate analysis of audit expense (continued)

Panel D: Mean (median) audit expense by fund type.

\begin{tabular}{|c|c|c|c|}
\hline & Closed-end fund & Open-end fund & $\begin{array}{l}\text { t-statistic for difference in means } \\
\text { (Z-statistic for diff. in medians) }\end{array}$ \\
\hline Equity fund & $\begin{array}{c}71018 \\
(52000)\end{array}$ & $\begin{array}{l}33053 \\
(27000)\end{array}$ & $\begin{array}{l}7.04^{* *} \\
(9.19)^{* *}\end{array}$ \\
\hline Debt fund & $\begin{array}{c}47620 \\
(40000)\end{array}$ & $\begin{array}{c}40043 \\
(33000)\end{array}$ & $\begin{array}{l}2.78^{* * *} \\
(5.20)^{* *}\end{array}$ \\
\hline Foreign fund & $\begin{array}{c}76474 \\
(71000)\end{array}$ & $\begin{array}{c}45430 \\
(37000)\end{array}$ & $\begin{array}{l}5.77^{* *} \\
(5.70)^{* *}\end{array}$ \\
\hline $\begin{array}{l}\text { Domestic } \\
\text { fund }\end{array}$ & $\begin{array}{c}54867 \\
(42000)\end{array}$ & $\begin{array}{l}32735 \\
(27000)\end{array}$ & $\begin{array}{l}6.80^{* *} \\
(8.93)^{* *}\end{array}$ \\
\hline $\begin{array}{l}\text { Large fund } \\
\text { family } \\
\text { Small fund } \\
\text { family }\end{array}$ & $\begin{array}{c}45267 \\
(39000) \\
74201 \\
(60000)\end{array}$ & $\begin{array}{c}40729 \\
(34000) \\
28252 \\
(22000)\end{array}$ & $\begin{array}{c}1.78 \\
(3.61)^{* *} \\
8.48^{* *} \\
(10.26)^{* *}\end{array}$ \\
\hline $\begin{array}{l}\text { Trades } \\
\text { Derivatives } \\
\text { No } \\
\text { Derivatives }\end{array}$ & $\begin{array}{c}61433 \\
(45500) \\
56384 \\
(43000)\end{array}$ & $\begin{array}{c}39256 \\
\left(\begin{array}{ll}31 & 000\end{array}\right) \\
32838 \\
(27000)\end{array}$ & $\begin{array}{l}4.25^{* *} \\
(9.04)^{* *} \\
6.82^{* *} \\
(5.87)^{* *}\end{array}$ \\
\hline $\begin{array}{l}\text { Restricted } \\
\text { Securities } \\
\text { No Restricted } \\
\text { Securities }\end{array}$ & $\begin{array}{c}75532 \\
(63000) \\
45091 \\
(39000)\end{array}$ & $\begin{array}{c}45488 \\
(36000) \\
31210 \\
(26000)\end{array}$ & $\begin{array}{c}5.89^{* *} \\
(8.79)^{* *} \\
4.51^{* *} \\
(5.39)^{* *}\end{array}$ \\
\hline Big-5 & $\begin{array}{c}58881 \\
(45500)\end{array}$ & $\begin{array}{c}36014 \\
(30000)\end{array}$ & $\begin{array}{c}7.49^{* *} \\
(10.05)^{* *}\end{array}$ \\
\hline Not Big-5 & $\begin{array}{c}48091 \\
(38500)\end{array}$ & $\begin{array}{c}17453 \\
(15000)\end{array}$ & $\begin{array}{c}4.42^{* *} \\
(4.94)^{* *}\end{array}$ \\
\hline Large fund & $\begin{array}{c}68161 \\
(51500)\end{array}$ & $\begin{array}{c}44251 \\
(35000)\end{array}$ & $\begin{array}{l}5.09^{* *} \\
(7.60)^{* *}\end{array}$ \\
\hline Small fund & $\begin{array}{c}48624 \\
(41000)\end{array}$ & $\begin{array}{c}24702 \\
(21000)\end{array}$ & $\begin{array}{l}7.24^{* *} \\
(6.64)^{* *}\end{array}$ \\
\hline High turnover & $\begin{array}{c}74556 \\
(61000)\end{array}$ & $\begin{array}{c}35891 \\
(30000)\end{array}$ & $\begin{array}{l}8.70^{* *} \\
(9.60)^{* *}\end{array}$ \\
\hline Low turnover & $\begin{array}{c}50562 \\
(40000)\end{array}$ & $\begin{array}{c}33038 \\
(27000)\end{array}$ & $\begin{array}{l}4.83^{* *} \\
(6.37)^{* *}\end{array}$ \\
\hline High cash & $\begin{array}{c}62318 \\
(48000)\end{array}$ & $\begin{array}{c}35914 \\
(29000)\end{array}$ & $\begin{array}{l}6.25^{* *} \\
(7.83)^{* *}\end{array}$ \\
\hline Low cash & $\begin{array}{c}54570 \\
(42000)\end{array}$ & $\begin{array}{c}33051 \\
(27000)\end{array}$ & $\begin{array}{l}5.40^{* *} \\
(6.91)^{* *}\end{array}$ \\
\hline
\end{tabular}


Table 3. Regression Analysis of Audit Expense

\begin{tabular}{|c|c|c|c|c|}
\hline & (1) & (2) & (3) & (4) \\
\hline Intercept & $\begin{array}{c}17192 \\
(11.26)^{* *}\end{array}$ & $\begin{array}{l}14559 \\
(8.26)^{* *}\end{array}$ & $\begin{array}{l}16503 \\
(9.29)^{* *}\end{array}$ & $\begin{array}{c}17153 \\
(11.31)^{* *}\end{array}$ \\
\hline Closed-end & $\begin{array}{c}22739 \\
(14.02)^{* *}\end{array}$ & $\begin{array}{c}30342 \\
(17.38)^{* *}\end{array}$ & $\begin{array}{l}-4,092 \\
(-0.79)\end{array}$ & $\begin{array}{c}22501 \\
(13.96)^{* *}\end{array}$ \\
\hline Fund Size $\left(x 10^{-5}\right)$ & $\begin{array}{c}.474 \\
(24.75)^{* * *}\end{array}$ & $\begin{array}{c}.571 \\
(25.64)^{* *}\end{array}$ & $\begin{array}{c}.569 \\
(25.68)^{* *}\end{array}$ & $\begin{array}{c}.447 \\
(23.23)^{* *}\end{array}$ \\
\hline Fund Size $e^{2}\left(x 10^{-14}\right)$ & $\begin{array}{c}-4.647 \\
(-16.59)^{* *}\end{array}$ & $\begin{array}{c}-5.665 \\
(-14.91)^{* *}\end{array}$ & $\begin{array}{c}-5.636 \\
(-14.90)^{* *}\end{array}$ & $\begin{array}{c}-4.369 \\
(-15.61)^{* *}\end{array}$ \\
\hline Equity & $\begin{array}{l}-2.572 \\
(-2.78)^{* *}\end{array}$ & $\begin{array}{c}-4,190 \\
(-4.40)^{* *}\end{array}$ & $\begin{array}{c}-4,889 \\
(-5.13)^{* *}\end{array}$ & $\begin{array}{c}-2,616 \\
(-2.85)^{* *}\end{array}$ \\
\hline Foreign & $\begin{array}{l}10,409 \\
(9.69)^{* *}\end{array}$ & $\begin{array}{c}8,625 \\
(8.03)^{* *}\end{array}$ & $\begin{array}{c}8,623 \\
(8.06)^{* *}\end{array}$ & $\begin{array}{l}10,519 \\
(9.86)^{* *}\end{array}$ \\
\hline Turnover & $\begin{array}{c}.002 \\
(0.95)\end{array}$ & $\begin{array}{l}-.004 \\
(-1.44)\end{array}$ & $\begin{array}{l}-.004 \\
(-1.42)\end{array}$ & $\begin{array}{c}.001 \\
(0.30)\end{array}$ \\
\hline Family Size $\left(x 10^{-9}\right)$ & $\begin{array}{l}-3.894 \\
(-1.87)\end{array}$ & $\begin{array}{l}-7.589 \\
(-2.43)^{*}\end{array}$ & $\begin{array}{c}-8.304 \\
(-2.67)^{* *}\end{array}$ & $\begin{array}{l}-3.694 \\
(-1.79)\end{array}$ \\
\hline Cash & $\begin{array}{c}-8.303 \\
(-3.38)^{* *}\end{array}$ & $\begin{array}{l}-12.574 \\
(-5.43)^{* *}\end{array}$ & $\begin{array}{l}-12.810 \\
(-5.56)^{* *}\end{array}$ & $\begin{array}{l}-9.656 \\
(-3.96)^{* *}\end{array}$ \\
\hline Derivatives & $\begin{array}{c}4,549 \\
(5.28)^{* *}\end{array}$ & $\begin{array}{c}5,582 \\
(6.52)^{* *}\end{array}$ & $\begin{array}{c}5,801 \\
(6.80)^{* *}\end{array}$ & $\begin{array}{c}4,880 \\
(5.69)^{* *}\end{array}$ \\
\hline Restricted Securities & $\begin{array}{c}8.259 \\
(9.19)^{* *}\end{array}$ & $\begin{array}{l}5,763 \\
(6.38)^{* *}\end{array}$ & $\begin{array}{c}5,340 \\
(5.93)^{* *}\end{array}$ & $\begin{array}{l}7,905 \\
(8.84)^{* *}\end{array}$ \\
\hline Big-5 & $\begin{array}{l}12136 \\
(8.99)^{* *}\end{array}$ & $\begin{array}{l}12692 \\
(9.52)^{* *}\end{array}$ & $\begin{array}{l}12324 \\
(9.27)^{* *}\end{array}$ & $\begin{array}{l}12664 \\
(9.44)^{* *}\end{array}$ \\
\hline $\begin{array}{l}\text { Marginal } \\
\text { Compensation } \\
\text { Closed-end*Marg. } \\
\text { Comp. }\end{array}$ & & $\begin{array}{l}4.916 \\
(3.73)^{* *}\end{array}$ & $\begin{array}{l}3.474 \\
(2.62)^{* *} \\
44.501 \\
(7.07)^{* *}\end{array}$ & \\
\hline Excess Expenses & & & & $\begin{array}{l}241.4 \\
(9.41)^{* *}\end{array}$ \\
\hline adj. $-R^{2}$ & 20.7 & 24.5 & 25.2 & 21.7 \\
\hline Obs. & 6,543 & 5,531 & 5,531 & 6,543 \\
\hline
\end{tabular}

The sample consists of 6,543 open-end and closed-end funds that filed annual N-SARs with the SEC in 2010. Closed-end is a dichotomous variable equal to one if a fund is closed-end and zero otherwise. Fund size is total fund net assets. Fund Size $e^{2}$ is the square of fund size. Equity is a dichotomous variable equal to one if a fund invests primarily in equity securities and zero otherwise. Foreign is a dichotomous variable equal to one if a fund invests primarily in foreign securities and zero otherwise. Turnover is the lesser of fund purchases or sales divided by average net assets value. Family Size is the total (within sample) net assets of the fund family. Cash is the percentage of cash relative to total fund assets. Derivatives is a dichotomous variable equal to one if a fund invests in derivative securities and zero otherwise. Restricted Securities is a dichotomous variable equal to one if a firm invests in restricted securities and zero otherwise. Big-5 is a dichotomous variable equal to one if the auditor is a Big-5 auditor and zero otherwise. Marginal Compensation is the change in advisor compensation given a small change in fund assets (given the advisory contract and the current level of fund assets). Excess Expenses is the residual from the regression of fund expenses on various fund characteristics. t-statistics are in parentheses. ${ }^{* *}$ indicates significance at the $1 \%$ level. ${ }^{*}$ indicates significance at the $5 \%$ level. 
Table 4. Additional Analysis of Audit Fees

\begin{tabular}{|c|c|c|c|c|c|c|c|c|c|}
\hline 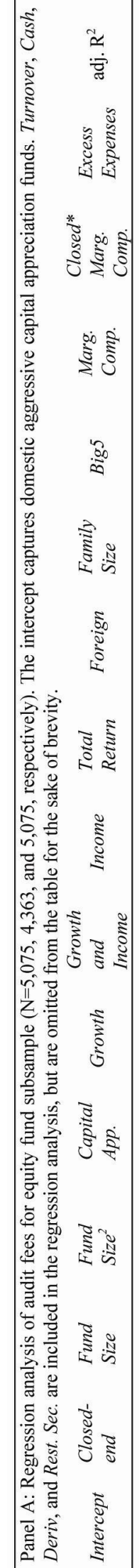 & 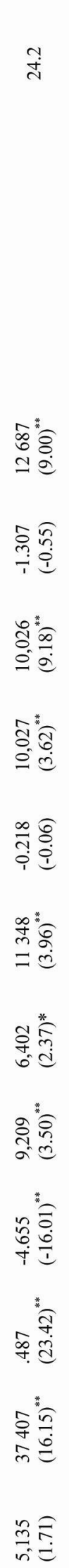 & 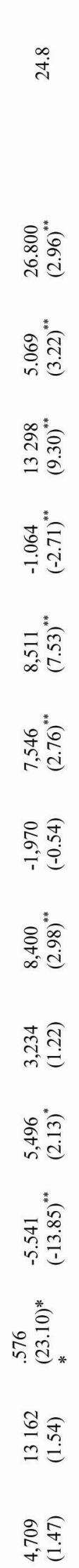 & 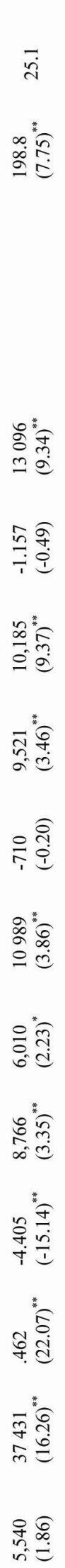 & 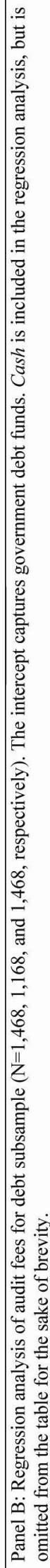 & 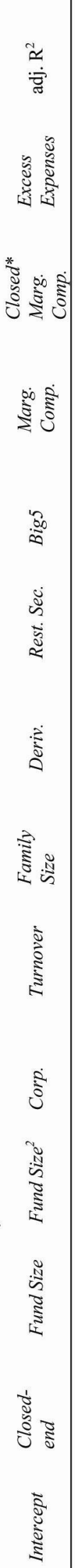 & 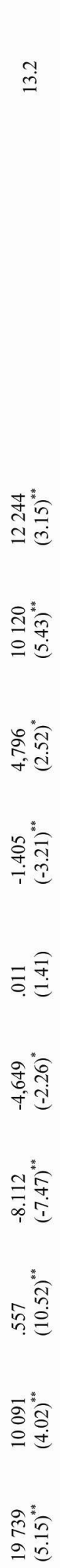 & 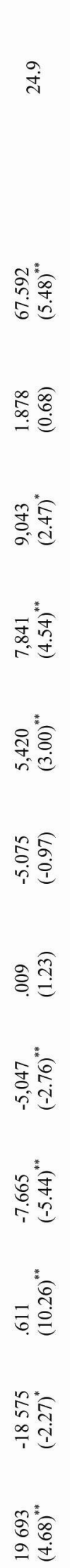 & 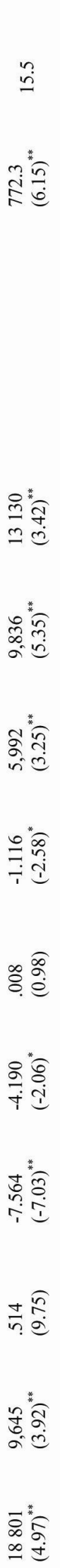 & 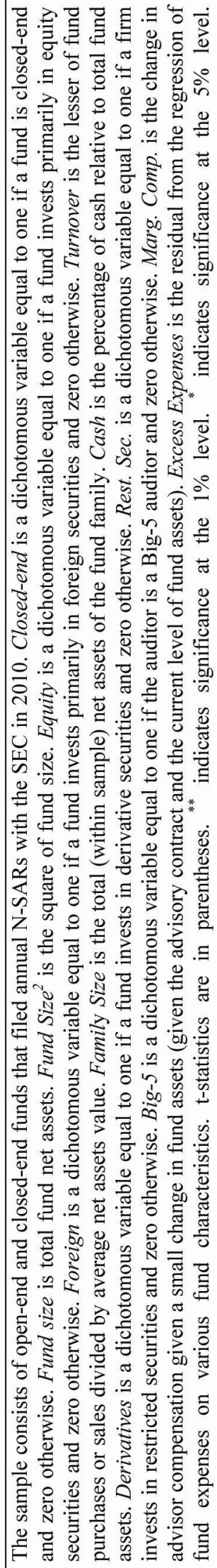 \\
\hline
\end{tabular}


Table 4. Additional Analysis of Audit Fees (continued)

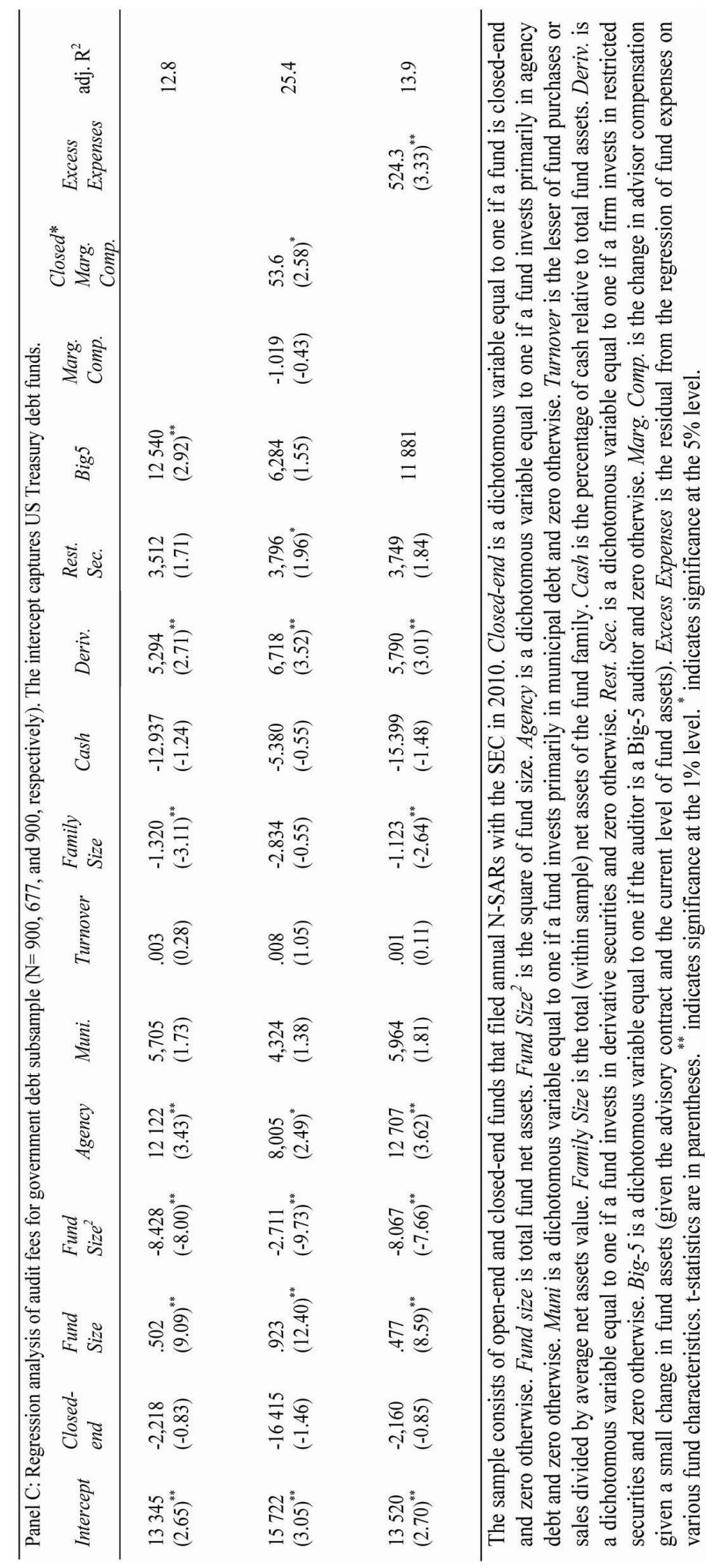

